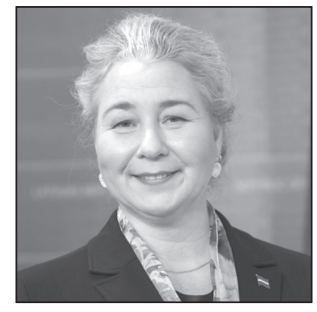

Ilona Kronberga

Doctoral student

University of Latvia

\title{
Life without Crime as a Fundamental Right of the Child:
}

\author{
On the Prevention of Juvenile Delinquency ${ }^{{ }^{*}}$
}

\section{Introduction}

The understanding of the rights of the child and their meaning differs between countries, as does the situation in the field of protection of children's rights. Very often, contradictory opinions flourish in society: some think that children have too many rights, while others recognise violation of the rights of the child even in cases wherein there is no violation at all. Although professional debate on topical problems, this issue among them, can be considered a part of diversity of opinion and therefore favourable, extreme opinions or actions that are based on common law instead of knowledge do not enhance healthy development of society, of which the children are an integral part. Still, there are several European countries where the rights of the child are not addressed by a separate branch of law and legal science; therefore, questions pertaining to the rights of the child fail to be brought into those states' academic debate and the knowledge of future lawyers and students of other sciences.

Rights of the child belong to a horizontal branch of law and legal sciences, and, in fact, issues of them permeate every part of the legal framework and social activity. This is because the rights of the child are the child's human rights. These are the rights of a human who grows, develops, learns, and gains life experience and maturity every day. They are the rights of a human who has not yet reached maturity but is in the process of personal development. This is what makes a child not a 'small adult'. Lack of such understanding sparks heated debate in cases that involve limitations to the rights of the child or, vice versa, the violation of these rights and appropriate reactions to it. Today, one such area of debate in Latvia surrounds juveniledelinquency prevention, responses to offences committed by children, and attitudes towards child victims involved in various proceedings of formal justice.

In 2007, analysis of the influence of traditional justice on children who are on the line of committing a crime or have already crossed this border led to the conclusion that it is important to understand that an offence committed by a juvenile as socially 'deformed' behaviour shows that the rights of this child have already been violated, earlier in his or her life, and that the child's interests have been neglected. Lack of care/consideration, indifference by parents and other adults, and reluctance to understand and to satisfy a child's needs all can lead to the child committing an offence. The child should be blamed for commission

1 This publication has been prepared on the basis of conclusions from studies in the fields of protection of children's rights and juvenile-delinquency prevention in Latvia and other European countries over the last six years. 
of the specific criminal offence at issue, while the state and the community should be held accountable for having created circumstances under which the child has decided to resolve his or her problems to the detriment of the community in violation of criminal law's taboos. However, instead of recognising its co-liability for the offence that has been committed and instead of considering ways in which to compensate for the negligence, the state contemplates the extent of the repression to impose on the offender for making him or her repent for the act committed and for preventing him or her from committing new criminal offences ${ }^{{ }^{*}}$.

It may be concluded from the foregoing that children who have been guaranteed an environment favourable for their development - who are loved, are cared for, and feel safe in their families - do not commit crimes and do not become crime victims as often as those who lack these conditions ${ }^{*} 3$. In line with this hypothesis, a study was conducted in 2012 through which it was verified that with the aid of timely and efficient prevention measures it is possible to decrease the number of children who are influenced by criminality ${ }^{*}$. In addition, the research allowed concluding that within the scope of prevention measures it is essential to strengthen the bond between the child and parents / parental surrogates, to ensure good relationships within the family, which ensure positive social relations and positive experience. The information gathered in the study confirmed, at the same time, the existence of deficiencies in the protection of the rights of the child and children's protection against crime: the respondents in the survey that formed part of the study indicated that it is extremely necessary in Latvia to develop a new legal framework in the field of juvenile justice as soon as possible, pointing out that the current mechanism is directed towards the child's inclusion in the formal system of justice whenever this is possible.

Studies conducted in the years since have shed light on two more problems that are significant from the perspective of protecting children from the impact of criminal surroundings. Problem 1 is that prevention activities cannot be organised as 'campaigns'; they have to be systematic and must be compulsory for parents (including other guardians etc.), involving them in order to enhance parents' participation in the building of their children's future and their taking of responsibility jointly with the children. ${ }^{*} 5$ The second problem is that prevention activities for children and their parents have to be carried out in a timely manner, from the birth of the child until the child comes of age; early prevention and intervention methods have to be used both to promote the child's personal development and to enhance parenting skills ${ }^{* 6}$.

\section{The legal framework in Latvia: A brief overview}

The State of Latvia safeguards every individual's human rights as stipulated in the Constitution of the Republic of Latvia (Satversme) and also honours legal acts of the European Union and European Council, along with other international legislation. In consideration of the age, maturity, and stage of development of each person, the rights of the child are separated from this general legal framework for purposes of ensuring the necessary legal protection for this segment of society. The principle is of a horizontal nature; accordingly, it extends to all fields of rights.

2 A. Judins. Restorative Justice vs Juvenile Delinquency: The Baltic States in European Dimension. Riga: PROVIDUS 2010. Available at http://providus.foo.lv/upload_file/Projekti/Kriminalitesibas/RJ_research.pdf (most recently accessed on 12.8.2016).

3 Latvijas Valsts policijas pārskats par nepilngadīgo noziedzības stāvokli, noziedzīgos nodarījumos cietušajiem bērniem un noziedzības novēršanas problēmām 2015.gadā ['The State Police of Latvia: Report on the situation with juvenile criminality, juvenile-crime victims, and crime-prevention problems, 2015'] (in Latvian). Available at http://www.vp.gov.lv/faili/sadalas/ parskats__2015.docx (most recently accessed on 12.8.2016).

4 I. Kronberga, J.Zermatten. Child-Friendly Justice in Latvia: Focusing on Crime Prevention. Riga: PROVIDUS 2012. Available at http://providus.lv/upload_file/Projekti/Kriminalitesibas/Child-friendly\%20Justice\%20in\%20Latvia.pdf (most recently accessed on 12.8.2016).

5 For description of a relevant project and research results, see the document 'Keeping Youth Away from Crime: Searching for Best European Practices', available at http://providus.lv/en/article/keeping-youth-away-from-crime-searching-forbest-european-practices (most recently accessed on 12.8.2016).

6 Description of the project and research results can be found in the document 'Supporting Children. Early Prevention Methods for Anti-social Behaviour Working with Pre-school and Primary School Children and Their Parents', available at http:// providus.lv/article_files/3172/original/Supporting_children_PROVIDUS_2015_eng.pdf?1457623278 (most recently accessed on 12.8.2016). 
Article 110 of the Constitution of the Republic of Latvia ${ }^{{ }^{*} 7}$ stipulates that the state protects and supports marriage as a union between a man and a woman, the family, the rights of parents, and rights of the child. The state shall ensure particular assistance to disabled children, orphans, and victimised children. This legal provision, specifying special protection with regard to several institutions, has a close relationship with material in other articles of the Constitution, stipulating the rights to social security, education, and protection of health $^{* 8}$. Thus, special status is given not only to the child as an 'under-age' person ${ }^{*} 9$ but also to the child's family and parents with regard to the responsibility of taking care of the child. Special attention is paid also to national responsibility with respect to children with health problems, children in situations of social risk, and children who have been victimised through other persons' illegal actions. Article 3, Part 2 of the Protection of the Rights of the Child Law ${ }^{*}$, in its turn, stipulates that the state guarantees special rights and freedoms to all children, irrespective of race, nationality, gender, language, political party alliance, political or religious convictions, national/ethnic or social origin, place of residence within the state, property or health status, and birth or other circumstances of the child (or of the child's parents, guardians, or family members). Thus, on one hand, the special legal status of the child - i.e., a person who has not reached the age of majority stipulated by law - has been established as valid until he or she reaches the legally stipulated age (representing a particular level of maturity), while, simultaneously, Article 177 of the Civil Law provides for the duties of those people who have a special status relative to the child as stipulated in the Constitution of the Republic of Latvia. Accordingly, the child is under the custody of his or her parents until reaching the age of majority. This custody confers the duties of parents to care for the child and the child's property and to represent the child in his or her personal and property relations, where 'care' refers to looking after the child, supervising him or her, and appropriately exercising the right to determine the child's place of residence. It is specified that care of the child includes the provision of food, clothing, a dwelling, and health care, along with tending of the child, seeing to his or her education, and ensuring the child's proper mental and physical development, while taking into account to the greatest extent possible the child's individuality, abilities, and interests and preparing the child for socially useful work. With regard to the safety of the child, it is indicated that supervision of the child means care for the child's safety and the prevention of endangerment by third parties.

The aim for this publication has been defined in consideration of the above: to provide the reader with analysis as a result of which it would be possible to conclude that a) the child's right to live without encountering criminality or its consequences ${ }^{{ }^{*} 11}$ and b) the existence of child-friendly justice ${ }^{*_{12}}$ are constitutional rights of the child provided for both in the Constitution of the Republic of Latvia and in other legal acts. International legal enactments, recommendations of the European Council, and legal provisions of the Republic of Latvia are analysed, and the analysis is followed by conclusions on the implementation of these legal provisions in the practice of the protection of children's rights.

\section{Child-friendly justice: The essence and content of the concept}

The concept of child-friendly justice encompasses not only the legal framework but also the aggregate of institutions, specialists, and procedures working particularly for children and youth to ensure their best interests. Although recommendations of the European Council and various international legal enactments require a child-appropriate system of justice, such a system does not function in Latvia, either in theory or in practice.

7 Latvijas Republikas Satversme: LR likums ['The Constitution of the Republic of Latvia: Law of the Republic of Latvia']. Latvijas Vēstnesis (official state publisher) 1993 (publication of 1 July, No. 43) (in Latvian).

8 Ibid., articles 109, 111, and 112.

9 In accordance with Article 219 of the Civil Law, people's minority continues until they attain the age of 18, whereas according to the Protection of the Rights of the Child Law (Article 3, Part 1), a child is a person who has not reached 18 years of age, excepting such persons as have been declared to be of legal age in accordance with the law or have entered into marriage before reaching 18 years of age.

10 Bèrnu tiesību aizsardzības likums: LR likums ['The Protection of the Rights of the Child Law: Law of the Republic of Latvia']. Latvijas Vēstnesis (official state publisher) 1998 (publication of 8 July, No. 199/200 (1260/1261)) (in Latvian).

11 Fundamental Rights Report 2016: Rights of the child. Available at http://fra.europa.eu/sites/default/files/fra_uploads/ fra-2016-frr-chapter-6-rights-of-the-child_en.pdf (most recently accessed on 12.6.2016).

12 Child-friendly justice. Available at http://www.coe.int/en/web/children/child-friendly-justice (most recently accessed on 12.6.2016). 
The concept of child-friendly justice was first explained in detail in 2010, when the guidelines of the Committee of Ministers of the Council of Europe on child-friendly justice ${ }^{{ }^{*} 13}$ came into force. This concept includes the notion of justice appropriate for children and young people, with the claim that children's and youth justice is a special provision for legal norms, institutions, specialists, and procedures ensuring, in particular, acting in the best interests of a child. ${ }^{*}{ }^{14}$ At the same time, the concept of child-friendly justice encompasses also the stipulation that a system of justice may be recognised as child-friendly only if it is accessible, age-appropriate for the child, fast, respectful, and in correspondence with and suitable for meeting the child's needs, and there is a requirement that its procedures honour all rights of the child, respect the child's right to participate and understand the process, and operate in line with the right to private and family life and integrity. Conformity or nonconformity with the principles mentioned above gives the answer as to whether or not the particular procedures or the overall system of justice in place may be deemed childfriendly. A child-friendly justice system extends beyond judicial power institutions, to every institution or process that a child may come across. The European Council gives an explanation on its Web site indicating that there are many distinct ways in which a child can come into contact with the justice system. It may be in relation to family matters such as divorce or adoption, or it might be the child's experience of administrative justice connected with nationality or immigration issues or of criminal justice as a victim of, witness to, or perpetrator of crime. It is pointed out that when faced with the justice system, children are thrown into an adult-managed system of relationships, which children, for reason of their age and lack of life experience and maturity, cannot understand, and that, therefore, judicial procedures wherein children are involved need to be adapted so as to be understandable for them. ${ }^{* 15}$ In this case, it does not matter whether the contact is with the police, a family court, or some other law-enforcement institution.

The concept of child-friendly justice is included in the concept of the welfare state ${ }^{* 16}$, where the duty of a welfare state is to support family, a solid education policy, and individuals who need special care. The welfare state is a 'social state' wherein the state takes the key role in seeing to provision of assistance also in burdensome life situations and ensuring suitable remuneration for other accidents of life; it entails caring about refugees, those who have lost their sight, etc.; helping in cases of natural disaster and failures; and compensating victims of crime or similar acts for the harm they have suffered. ${ }^{* 17} \mathrm{~A}$ social state, in turn, is a state that has not only rights but also duties to be active and interfere with the legal order in social life to take responsibility for its inhabitants and their social protection. ${ }^{*} 18$ Protection of children as a special category of inhabitants has to be included in this social protection. The Constitutional Court of the Republic of Latvia has indicated that also the duty to protect the weak and ensure social justice and protection in the event of social risks is included in the concept of the socially responsible state. ${ }^{*} 19$

The practical part of the implementation of legal norms, however, differs from what is stipulated in legal enactments and recommendations of the European Council. Often, there are cases wherein the best interests of the child play a secondary role especially with regard to the practical issues of implementing prevention of child delinquency. ${ }^{* 20}$ Studies show that for taking into consideration the problems in creating a child-friendly environment (including difficulties in the judicial realm), presented in the 2013-2014 guidelines for prevention of children's crime and protection of children against criminal offences ${ }^{* 21}$, the

13 Guidelines of the Committee of Ministers of the Council of Europe on child friendly justice (adopted by the Committee of Ministers on 17 November 2010 at the 1098th meeting of the Ministers' Deputies). Available at https://search.coe.int/cm/ Pages/result_details.aspx?ObjectID=09000016804b2cf3 (most recently accessed on 12.6.2016).

14 I. Kronberga, S. Sīle. Kā radīt bērna attīstībai labvēlīgu vidi? ['How to Create an Environment Favourable for a Child's Development']. Riga: Providus 2015 (in Latvian), on p. 3.

15 Child-friendly justice (see Note 12).

16 R. Cipelius. Vispārējā mācība par valsti ['General Theory of State’]. Riga: AGB 1998 (in Latvian), on pp. 275-276.

17 Ibid., p. 275.

18 J. Pleps et al. Konstitucionālās tiesības. Papildināts un pārstrādāts izdevums ['Constitutional Rights, Revised and Expanded Edition']. Riga: Latvijas Vēstnesis (official state publisher) 2014 (in Latvian).

19 Ibid., p. 148.

20 I. Kronberga, S. Sīle. Antisociālas uzvedības agrīnās prevencijas metodes darbam ar pirmsskolas un sākumskolas bērniem un viņu vecākiem ['A method of early prevention of anti-social behaviour for pre-school and primary-school children and their parents']. Riga: Providus 2015 (in Latvian), pp. 36-39. Available at http://providus.foo.lv/upload_file/Publikacijas/ Kriminalt/2014/Visi.raksti_LV.pdf (most recently accessed on 12.6.2016).

21 Bērnu noziedzības novēršanas un bērnu aizsardzības pret noziedzīgu nodarījumu pamatnostādnes 2013.-2019.gadam ['Prevention of crime among children and protection of children against criminal offence, guidelines for 2013-2019'] (in Latvian). Available at http://likumi.lv/doc.php?id=259219 (most recently accessed on 12.6.2016). 
National Family Policy Guidelines for 2011-2017 should be consulted. The latter guidelines list several problems that have not yet received any solution, including those of the absence of an effective system for preventing child delinquency and crimes against children, a high number of cases of children being traumatised, social vulnerability, and social rejection. ${ }^{{ }^{2} 2}$

\section{The child's right to avoid criminality and its harmful consequences}

Contact with crime has a particularly negative impact on a child (on account of the child's specific needs related to maturity, age, and development-linked considerations), whatever the formal status or reason for that contact - whether the child is an offender, a witness, or a victim. Therefore, it is essential to develop such methods in the system of rights protection as would reduce the number of cases in which children face formal justice. One of the ways to protect a child from the effects of coming in contact with criminal actions and to ensure the child's right to avoid criminality and its harmful consequences is prevention. Among the rights of the child is the right to full, holistic development. If a child commits a crime or is subject to physically or emotionally traumatic experiences as a victim or witness to crime, this influences his or her future well-being. Therefore, prevention is clearly among the ways to protect a child from effects of contact with criminality in all its possible variations. Effective development and functioning of the prevention system is a tool for ensuring that the child's basic rights to development and protection are honoured in a qualitative manner in accordance with the Constitution of the Republic of Latvia and other legal norms.

Recommendations from the Committee of Ministers of the Council of Europe on the role of early psychosocial intervention in the prevention of criminality ${ }^{* 23}$ define the prevention of criminality as including activities aimed at preventing the likelihood of criminal action and future persistent criminal behaviour. If one is to prevent children from encountering criminality, it is necessary to:

a) create a system aimed at recognition and prevention of risk factors in the child's social environment and the child's behaviour in a timely manner, in which context risk factors can be divided into internal and external risks, where external risk factors are not dependent on the child or the child's behaviour or choice (these are 'risk situations', among which are parental divorce, death of a relative, poor parenting, and other factors) and internal risk factors depend on the child's personality, behaviour, reactions to environmental impulses or events, and relations with educators at school or pre-school education institutions (internal risk factors, or 'behavioural risks', have to be considered already as consequences that emerge from unresolved risk situations, and among the behavioural risks that may be expressed in a child's behaviour are active anti-social behaviour, including aggression against others or the child him- or herself, as well as various types of passive behaviour that are harmful - for instance, taking of a victim's role, tearfulness, or reservedness); ${ }^{*}{ }^{24}$

b) plan and perform timely social interventions in order to strengthen protective factors in the child's life, thereby decreasing risk factors, where the concept of child-protective factors is defined in opposition to that of behavioural risks, as positive social roots lying in a good relationship with family members or teachers, which might be expressed in a hobby such as sports, music, or travelling (protective factors need to be strengthened through social interventions: targeted, timely, and definitely positive interference in the child's life carried out to, for instance, strengthen parenting skills, create positive affect and activate protective factors, enhance the child's self-esteem and belief in his or her skills, and increase the child's understanding of the processes under way in the community);

22 I. Kronberga et al. Bērnu sociāla iekl̦aušana kā antisociālas uzvedības novēršanas metode ['Children's Social Inclusion as a Method of Preventing Anti-social Behaviour']. Riga: Providus 2014 (in Latvian), on pp. 29-34.

23 Recommendation R (2000) 20 of the Committee of Ministers to Member States, on the role of early psychosocial intervention in the prevention of criminality. Available via http://www.coe.int/t/dghl/standardsetting/prisons/PCCP\%20documents\%202013/Rec(2000)20_E.pdf (most recently accessed on 12.6.2016).

24 I. Kronberga, S. Sīle. Meklējot labāko Eiropas praksi jauniešu noziedzības novēršanai. Kopsavilkums ['Keeping Youth Away from Crime: Searching for Best European Practices, a Summary']. Riga: Providus 2015 (in Latvian), on pp. 56-62. Available at http://providus.lv/article_files/2890/original/keeping_lv.pdf?1427962796 (most recently accessed on 13.6.2016). 
c) strengthen parental skills so that the child's parents or persons who act in a corresponding role better understand the child's behaviour and reasons for risk appearing and have the skills necessary for reacting in a timely manner to the risks recognised in the child's behaviour or surroundings, or for preventing such risks from being actualised at all; and

d) develop methods for use in implementing early psychosocial interventions before the child can become a crime victim, witness criminal acts, or commit acts contrary to the law, where early psychosocial interventions are any actions that strengthen protective factors, healthy affection, and parenting skills (these are activities that improve the child's communication and mutual understanding with the family, parents/guardians, and other people who play essential roles in the child's life in a particular period of time, and such activities are performed in accordance with the best interests of the child, in a child-friendly manner and with the active involvement of the child ${ }^{*} 25$ in the process).

The study conducted in $2012^{*_{2} 6}$ included in-depth analysis of the situation in Latvia with regard to prevention of child-committed crime. Among the conclusions drawn is that prevention activities, as stipulated in Article 58 of the Protection of the Rights of the Child Law, for children who face risk situations or display behavioural risks are implemented only in some particular municipalities. In cases of a child having committed an administrative offence, administrative penalties in the form of fines, usually paid by the parents, are implemented instead of compulsory measures as stipulated in the law On Compulsory Measures of a Correctional Nature ${ }^{*}$. Hence, two problems exist - poor performance of the prevention system and ineffective reactions to administrative offences committed by children. ${ }^{*} 28$ In 2015 , the situation in the implementation of law in practice had not changed significantly ${ }^{* 29}$, and the legal framework in the field of prevention of the violation of children's rights is fragmentary (for instance, inter-institution co-operation procedure and other mechanisms are not specified) and scattered, as the various stages of prevention are regulated by several individual legal acts and do not involve mutually connected procedures (for instance, the implementation of compulsory measures of a correctional nature is not connected to the legal order stipulated in Article 58 of the Protection of the Rights of the Child Law). Taking that into consideration, one finds no grounds for assuming that Latvia has done everything possible to ensure fulfilment of the right of the child to avoid criminality and its harmful consequences.

\section{Criminal-law relations in the domain of juvenile justice}

In the event that a child has come into contact with the formal justice system, has violated the law, has been victimised through other individuals' illegal actions, or has become a witness of such actions, the mechanisms applied to regulate relations under criminal law should be oriented primarily towards the best interests of the child (young person) - i.e., toward his or her rights to emotional and physical health and development. The principles of juvenile justice that are covered by the recommendations of the European Council $^{*} 30$ are in line with the scope of principles for protection of the rights of the child as stipulated in

25 For further information about child participation, see T. Liefaard et al. Can Anyone Hear Me? Participation of Children in Juvenile Justice: A Manual on How to Make European Juvenile Justice Systems Child-Friendly. Brussels: IJJO 2016.

26 I. Kronberga, Ž. Zarmatēns. Bērniem draudzīga tiesiskā vide Latvijā: fokusā likumpārkāpumu prevencija ['Child-Friendly Justice in Latvia: Focusing on Crime Prevention']. Riga: Providus 2012 (in Latvian), on pp. 19-36. Available at http:// providus.lv/upload_file/Projekti/Kriminalitesibas/Berniem_draudziga_tiesiska_vide_LV_1.pdf (most recently accessed on 14.6.2016).

27 Par audzinoša rakstura piespiedu līdzekḷu piemērošanu bērniem: LR likums ['The Law "On Compulsory Measures of a Correctional Nature": Law of the Republic of Latvia']. Latvijas Vēstnesis (official state publisher) 2002 (publication of 12 December, No. 168 (2743)) (in Latvian).

28 Latvijas Republikas Tiesībsarga 2011. gada ziņojums bērnu tiesību jomā ['Ombudsman's Report on Juvenile Justice in Latvia, 2011'] (in Latvian), on pp. 42-58. Available at http://www.tiesibsargs.lv/files/content/Tiesibsarga\%20Bernu\%20 tiesibu\%20jomas\%20gada\%20zinojums_2011.pdf (most recently accessed on 12.6.2016).

29 Tiesībsarga pētījums par vardarbības izplatību pret bērniem Latvijāa ['Ombudsman's Study of Cases Brought against Children for Violence in Latvia’]. Riga: TNS 2015 (in Latvian). Available at http://www.tiesibsargs.lv/files/content/ Petijumi/4239_TNS_Vardarbibas_pret_berniem_izplatiba_Latvija_2015.pdf (most recently accessed on 14.6.2016).

30 Child-friendly justice (see Note 12). 
the Constitution of the Republic of Latvia and the Civil Law. However, further legal mechanisms do not always retain the objective that is part of these principles. For instance, the recommendation of the Committee of Ministers of the European Council on social reactions to juvenile delinquency ${ }^{*}{ }^{31}$ stipulates that any reactions or punishments that concern minors should be focused on the integration and education of this target group and that the moment of the implementation of criminal punishment should be delayed as much as possible, in particular if it is related to isolation from society, and in the context of this legal enactment, it was recommended already in 1987 that Member States review national legal provisions and the practice of their implementation, with emphasis on (and development of) diverse preventive measures, among them various types of mediation ${ }^{*} 32$ and forms of social intervention. At the same time, the European Council has recommended conducting studies regularly to clarify whether the criminal-punishment policy and the practical implementation of legal provisions comply with the principles for juvenile justice. It can be concluded from this that there is a statement that children and young people should be involved in relations through criminal law only in cases of all other possible prevention measures having failed, whilst poorly developed preventive mechanisms or the lack of them cannot serve as an excuse for involving children and youth in relations under criminal law. In order to create uniform practice of rights implementation, several states are in the process of developing special legal provisions particularly for children and young people ${ }^{*} 3$. One of the latest legal enactments in the field is the Juvenile Justice (Care and Protection of Children) Act, which came into force recently (on 15 January 2016) in India. ${ }^{*} 34$ The situation with juvenile justice in Latvia, however, has not changed significantly since the mid-199os. Although several pieces of national legislation have been adopted in this time that have been aimed at improving the situation, significant systemic changes have not been planned and made ${ }^{*} 35$. Although there is a possibility of implementing a compulsory measure of correctional nature under the law On Compulsory Measures of a Correctional Nature instead of a punishment under the Criminal Law, only $3 \%$ of minors, on average, have been given a sentence with compulsory measures of a correctional nature by the court each year since the latter measures were first provided for. This allows us to conclude that in most cases the traditional system of criminal justice has been implemented for juveniles. That runs counter to the interests of the minor and either fails to promote or even eliminates the opportunity of the juvenile's resocialisation.

Therefore, on 30 August 2016, the Cabinet of Ministers of the Republic of Latvia accepted an informational report ${ }^{*} 36$ on the reform of the criminal-liability system for juveniles'. This report is a result of long-term studies and successful co-operation between the Ministry of Justice of Latvia and both local municipalities and NGOs in Latvia and abroad. The report includes a plan for further action and envisages conceptual governmental support for continued work on reforms to the juvenile criminal-liability system in Latvia with the aim of reducing the number of juveniles involved in the traditional system of criminal liability. At the same time, the necessary activities are addressed in the informational report on implementing Directive (EU) 2016/800 of the European Parliament and of the Council of Europe of 11 May 2016 on procedural safeguards for children who are suspects or accused persons in criminal

31 Recommendation R (87) 20 of the Committee of Ministers to Member States, on social reactions to juvenile delinquency (adopted by the Committee of Ministers on 17 September 1987 at the 410th meeting of the Ministers' Deputies). Available via http://www.coe.int/t/dghl/standardsetting/family/Resolutions_recommendations_cm_en.asp (most recently accessed on 11.6.2016).

32 Ibid., articles $2-3$.

33 For more details, please see I. Kronberga. Meklējot labāko Eiropas praksi jauniešu noziedzības novēršanai ['Searching for the best practice to prevent juvenile delinquency'] (in Latvian). Available at http://providus.lv/upload_file/Projekti/Kriminalitesibas/v2_Mekl\%C4\%93jot\%20lab\%C4\%81ko\%20Eiropas\%20praksi.pdf (most recently accessed on 10.6.2016).

34 The official report on the law coming into force is available at http://egazette.nic.in/WriteReadData/2016/167578.pdf, whereas the text of the new Juvenile Justice Act of India is available at http://www.prsindia.org/uploads/media/Juvenile\%20 Justice/Juvenile\%20justice\%20Bill,\%20\%202014.pdf (both most recently accessed on 10.6.2016).

35 As the Law On Compulsory Measures of a Correctional Nature came into force on 1 January 2005, it had to serve also as the tool for juvenile justice. However, actions were not taken to implement the provisions of the new law systematically. Therefore, several of the activities provided for by the act were not implemented at all. For instance, among these actions were apologising to the victim, being prohibited from being present in specific places, and being subjected to behavioural limits set for the child in question.

36 This highly informative report, titled 'Par nepilngadīgo kriminālatbildības sistēmas reformu" Latvijas Republikas Ministru kabinetam' (meaning 'On the reform of the juvenile criminal-liability system'), was prepared for the Cabinet of Ministers of the Republic of Latvia). The report is available, in Latvian, at http://tap.mk.gov.lv/doc/2016_08/TMZino_240816_juvenile.1817.docx (most recently accessed on 1.9.2016). 
proceedings ${ }^{*} 3$ in Latvia. It is emphasised in this report to the government of Latvia that the reform of the juvenile criminal-justice system should be based on the principles of restorative justice, whereas the aim for traditional criminal justice is to punish the guilty person - which goes against the interests of the child or young person even if a crime has been committed, in that an immature person should be guaranteed the protection of his or her interests and rights to develop, to grow, and to become a valuable member of society. The child's rights to development (which includes education, an environment favourable to development, and physical and mental health) are human rights of the child on the basis of his or her age and maturity level.

To ensure honouring these specific human rights of the child, the Law on Prevention of Antisocial Behaviour in Children is in the process of development. This law is to stipulate all preventive measures to ensure that anti-social behaviour does not develop in children and to cover supportive measures for children and their parents in cases of the child having violated legal provisions. The law is to regulate primary, secondary, and tertiary prevention activities, with particular emphasis on the role of children's parents and family. It is planned that the law will enter force on 1 January 2019.

\section{Conclusions}

Issues related to the rights of the child in Latvia have very often been seen only through the prism of welfare. However, within the last decade the European Parliament and the European Council have adopted a list of conceptual acts and recommendations to Member States that allow concluding that the field to do with the rights of the child is a separate branch of human rights with a horizontal nature. Children's rights cut across all fields of rights - civil, administrative, and other rights. Issues that involve children's rights should be addressed with particular care in the development of provisions for implementation of criminal law and punishment mechanisms, as these limit human rights. It should be stressed that human rights of the child are specific and differ from the human rights of an adult in their content and quantity because the child has specific needs in accordance with his or her age and level of maturity. Contact with the formal system of justice and, in particular, the weak mechanisms of crime prevention create increased likelihood of a child becoming an offender or suffering the impact of illegal acts committed by other individuals. Thereby, the child directly encounters harmful manifestations and consequences of criminality as a social phenomenon. The results of said contact delay and otherwise impair the development of the child; increase his or her exclusion from the community; and leave long-lasting psychological, emotional, and social footprints in the child's life. In consequence, the core specific rights of the immature child and young person to holistic, full development are violated. In order to prevent children from contact with criminality and protect children's human rights, systems for prevention of anti-social behaviour in children and for children's protection from criminality should be developed and improved.

37 Directive (EU) 2016/800 of the European Parliament and of the Council of 11 May 2016 on procedural safeguards for children who are suspects or accused persons in criminal proceedings. Available at http://eur-lex.europa.eu/legal-content/EN/ TXT/?uri=OJ\%3AJOL_2016_132_R_0001 (most recently accessed on 1.9.2016). 